\title{
Endoscopic gastrojejunostomy - bigger is better
}

A 55-year-old man with a history of multiple gunshot wounds complicated by dense adhesions from several previous episodes of abdominal surgery presented with persistent nausea/vomiting. His past medical history included a chronic enterocutaneous fistula, which had been closed with an atrial septal occluder. Additionally, he had had vomiting due to a duodenal stricture secondary to adhesions and he had undergone endoscopic ultrasound (EUS)-guided gastrojejunostomy with a lumen-apposing metal stent (LAMS). This had been complicated by stent misdeployment that required placement of a second tandem LAMS. The patient had reported improvement in his quality of life after closure of the enterocutaneous fistula and weight gain after undergoing the gastrojejunostomy. However, 6 months later, he developed recurrent nausea/vomiting.

During endoscopy, the previously placed 15-mm LAMS had evidence of tissue ingrowth through the eroded plastic covering, which was causing there to be a smaller gastrojejunostomy lumen. The stent was dilated with a $15-\mathrm{mm}$ controlled radial expansion balloon, which permitted the endoscope to be advanced into the small intestine. However, the LAMS could not be removed because of tissue ingrowth. Therefore, argon plasma coagulation (APC) was used to break the mesh of the stent ( $\triangleright$ Fig. 1). A 20-mm LAMS was then deployed across the previous stent under endoscopic and fluoroscopic guidance ( $\downarrow$ Video 1 ). The new stent was anchored with a $7-\mathrm{Fr} \times 15-\mathrm{cm}$ plastic double-pigtail stent. Following placement of the 20-mm LAMS, the patient's symptoms of nausea and vomiting improved considerably.

EUS-guided gastrojejunostomy has previously been shown to be successful for the management of gastric outlet obstruction secondary to benign and malignant disease [1,2]. Previous studies have utilized LAMS of $10 \mathrm{~mm}$ and $15 \mathrm{~mm}$ in diameter. Nonetheless, the smaller diam-

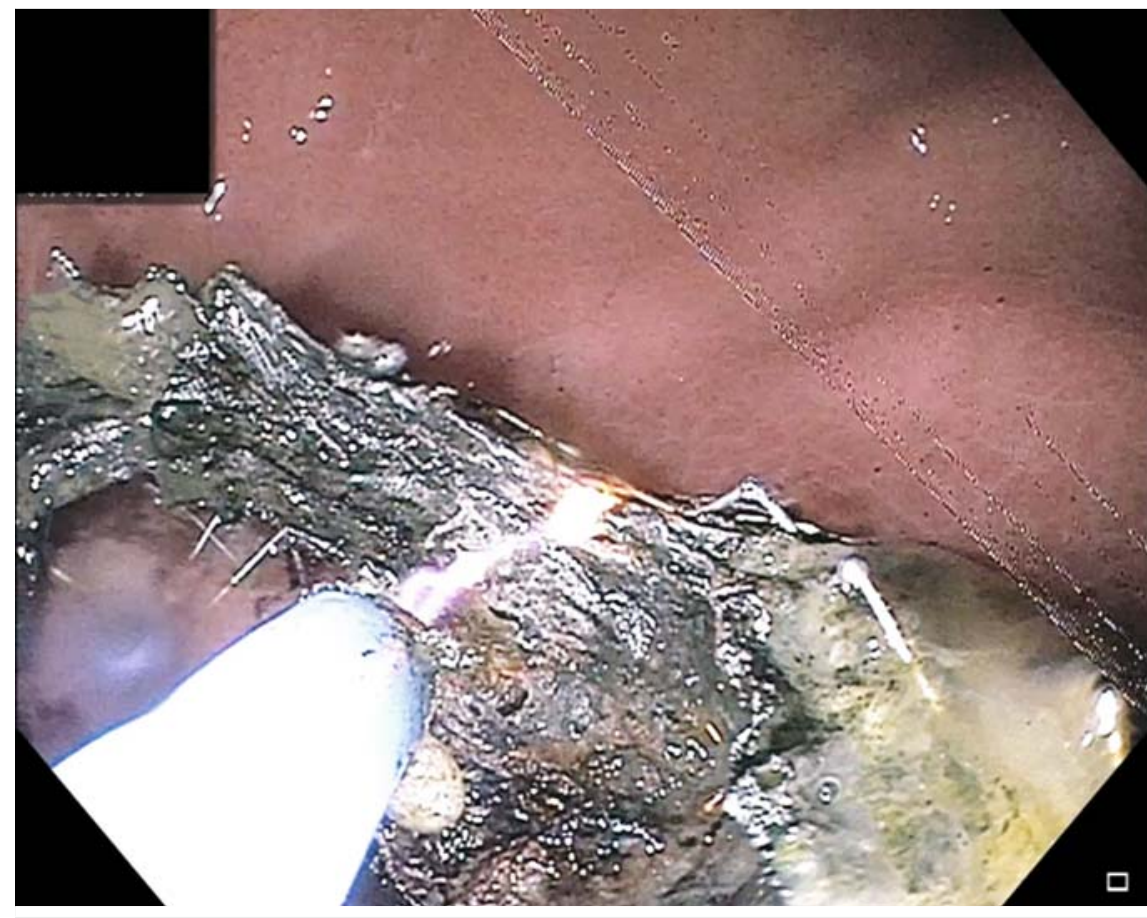

- Fig. 1 Endoscopic image showing argon plasma coagulation being used to detach the lumen-apposing metal stent that had been narrowed by tissue ingrowth.

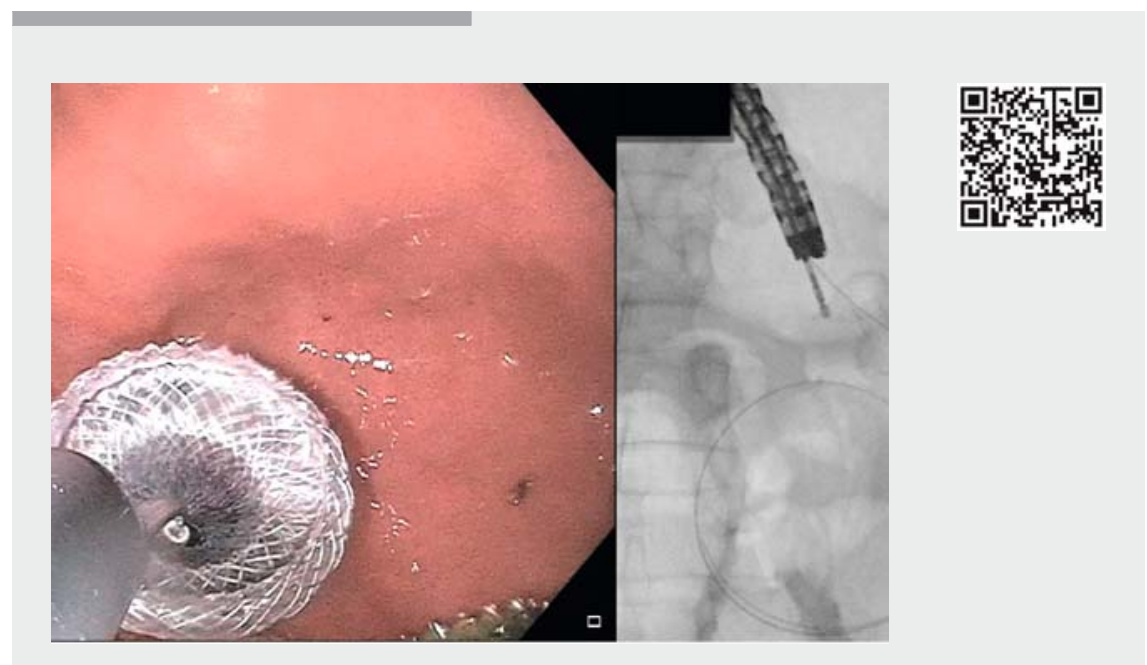

$\square$ Video 1 Endoscopic and radiographic views showing deployment of a 20-mm lumenapposing metal stent across the previous $15-\mathrm{mm}$ stent.

eter can lead to stent obstruction, either by tissue ingrowth or food. With the advent of the 20-mm LAMS, patients can now undergo successful larger diameter gastrojejunostomy. Future studies will be needed to determine whether the larger lumen will improve the overall nutrition and health of these patients. 
Endoscopy_UCTN_Code_CPL_1AH_2AD

Competing interests

Dr. R. Sharaiha is a consultant for Boston Scientific, Apollo and Olympus.

The authors

Luai Madanat, Monica Saumoy, Reem Z. Sharaiha

Weill Cornell Medicine, New York Presbyterian Hospital, New York, New York, USA
Corresponding author

\section{Reem Z. Sharaiha, MD, MSc}

Weill Cornell Medicine, Division of Gastroenterology and Hepatology, Department of Medicine, 1305 York Avenue, 4th Floor, New York, New York 10021, USA

Fax: +1-646-962-0110

rzs9001@med.cornell.edu

\section{References}

[1] Tyberg A, Perez-Miranda M, Sanchez-Ocaña $R$ et al. Endoscopic ultrasound-guided gastrojejunostomy with a lumen-apposing metal stent: a multicenter, international experience. Endosc Int Open 2016; 4: E276-E281

[2] Perez-Miranda M, Tyberg A, Poletto D et al. EUS-guided gastrojejunostomy versus laparoscopic gastrojejunostomy. J Clin Gastroenterol 2017; 51: 896-899

\section{Bibliography}

DOI https://doi.org/10.1055/a-0640-2630

Published online: 10.9.2018

Endoscopy 2018; 50: E331-E332

(c) Georg Thieme Verlag KG

Stuttgart · New York

ISSN 0013-726X

\section{ENDOSCOPY E-VIDEOS \\ https://eref.thieme.de/e-videos}

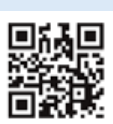

Endoscopy E-Videos is a free

回和: access online section, reporting on interesting cases and new

techniques in gastroenterological endoscopy. All papers include a high quality video and all contributions are freely accessible online.

This section has its own submission website at https://mc.manuscriptcentral.com/e-videos 